\title{
Questions about NeoDarwinism: a review of two books
}

\author{
Egbert Giles Leigh Jr.
}

\author{
Book Details \\ Mind and Cosmos: Why the Materialist NeoDarwinian Conception of Nature is Almost Certainly False, by Thomas Nagel. \\ New York: Oxford University Press, 2012. Pp. x + 130. ISBN 978-0-19-991975-8. Hb, \$24.95. \\ Are You an Illusion?, by Mary Midgley. New York, NY: Routledge. 2014. Pp. viii + 167. ISBN 978-1-84465-792-6. Pb, \$23.95 \\ Keywords: Basis of morality, Common good of autosomal genes, Consciousness, Fairness of meiosis, \\ Interdependence and morality, Natural selection, Objective knowledge, Objective moral rules, Objective reasoning, \\ Objective thought, Origin of intentionality, Reason, Selfish genes
}

These two books raise serious questions about various aspects of modern evolutionary theory. Do mind and consciousness have a material basis? Could consciousness, conceptual thought or morality evolve by natural selection? Could physico-chemical processes account for the origin of life? What can natural selection of "random" mutation do? These books do not advocate creationism or "intelligent design" or exaggerate the difference between humanity and other animals. They raise questions that evolutionary theory poses many humanists of good will, questions widely enough shared to deserve serious attention. Do their questions reflect a failure of we evolutionary biologists to communicate effectively, or real flaws in our message?

Thomas Nagel's Mind and Cosmos, published when he was 75 , argues (p. 4) that "psychophysical reductionism, a position in the philosophy of mind that is largely motivated by the hope of showing how the physical sciences could in principle provide a theory of everything," has failed. He asserts (p. 9) that the reductionist account of life faces "problems of probability... both with respect to the evolution of life forms through accidental mutation and natural selection and with respect to the formation from dead matter of physical systems capable of such evolution. The more we learn about the intricacy of the

*Correspondence: bufotyphonius@gmail.com

Smithsonian Tropical Research Institute, Panama 0843-03092, Republic of Panama genetic code and its control over the chemical processes of life, the harder these problems seem." Although I disagree with Nagel's major theses, his book has forced me to think about many topics, and I am most grateful that he wrote it. Indeed, answering these questions should help bring the sciences and the humanities closer together.

Nagel does not appreciate what natural selection can do. On p. 94 he claims that assuming "accidental mutations provided the set of successive candidates on which natural selection operated to generate the history of life" makes "the outcome too accidental to count as a genuine explanation of the existence of conscious, thinking beings as such." Fisher (1930, p. 37) said of such arguments "The income derived from a Casino by its proprietor may, in one sense, be said to depend on a succession of favourable chances, although the phrase contains a suggestion of improbability more appropriate to the hopes of the patrons of his establishment. It is easy... to perceive the difference between a succession of favourable deviations from the laws of chance, and... the continuous and cumulative action of those laws. It is on the latter that the principle of Natural Selection depends." Nagel (p. 10) cites Michael Behe's (1996) Darwin's Black Box, with approval, not because he accepts intelligent design, but because he believes Behe points out seemingly insuperable difficulties in selection theory. He does not directly cite Behe's "irreducible complexity" argument, but I presume he, like Behe, rejects the idea that complex adaptations can evolve by steps so small or simple that each step 
could occur as a chance mutation. I will return to this issue later.

Nagel feels on much surer ground in rejecting the origin of life as a purely physico-chemical process. If he is right, Putnam (1992, p. 33) is just to assert "evolution will not give you any more intentionality than you pack into it." Recent work on sea-bottom alkaline vents (Lane 2015), however, may overthrow Nagel's view. In these structures, molecular hydrogen vented in water from the magma below meets the carbon dioxide in the oceans, providing a steady energy supply, and an ever-renewing stock of bacteria-sized bubbles with semipermeable walls of iron sulphide, studded with catalytic compounds of iron, nickel and sulphur. In alkaline vents, chemical reactions can form organic compounds needed for life's origin. These vents provide a place where steps toward the origin of life can occur one after another rather than all at once. The issue of how life began is far from settled, but if, as seems increasingly likely, self-replicating entities can emerge from purposeless chemical reactions, selection would soon transform these entities into beings that intend to do what is needed to survive and reproduce.

Nagel (p. 35) believes that consciousness is the biggest obstacle to a naturalism based only on physical science, declaring (p. 71) "Consciousness presents a problem for evolutionary reductionism because of its irreducibly subjective character." Consciousness is a mystery: even now, explaining it in terms of physics and chemistry is hardly more than a hope. The mathematical physicist H. Weyl (2009, p. 197) illustrates the limits of science by the "riddle posed by the double nature of the ego... On the one hand, I am a real individual man... carrying out real physical and psychical acts. On the other hand, I am 'vision' open to reason, a self-penetrating light, immanent sense-giving consciousness..." In his greatest book, the ethologist Konrad Lorenz (1978, p. 169) remarked on "that most mysterious of barriers, utterly impenetrable to human understanding, that runs through the middle of the undeniable one-ness of our personality-the barrier that divides our subjective experience from the objective, verifiable physiological events that occur in our body." Lorenz (1978, p. 170) asserted "The autonomy of personal experience and its laws cannot in principle be explained in terms of physical and chemical laws or of neuro-physiological structure, however complex." Jacques Monod (1971, p. 159), who was far more interested in evolution and behavior than his fellow molecular biologists, remarked that consciousness is a "frontier, still almost as impassable for us as it was for Descartes... We today are no less in the habit of differentiating brain from mind than they were in the eighteenth century. Objective analysis obliges us to see that this seeming duality within us is a delusion. But it is... so intimately rooted in our being, that nothing could be vainer than to hope to dissipate it in the immediate awareness of subjectivity, or to learn to live emotionally and morally without it." (The phrase "objective analysis" should give Mary Midgley a good laugh). More recently, Changeux (2008) has been investigating the neurobiology of consciousness. Consciousness is so firmly rooted in the brain, and so essential to its possessors, that natural selection must be able to shape it. Many subjective experiences, like pain, have objectively observable neurobiological correlates, a circumstance that gives me but not Nagel (p. 38-41), hope that we may eventually have some objective understanding of consciousness. Nonetheless, Changeux (2008, p. 19, my translation) confesses "To be sure, in spite of all these discoveries, all these advances, we have as yet only babblings about the neuroscience of consciousness..."

Nagel also believes that natural selection cannot explain our ability to know objectively and reason effectively. He is rightly revolted (p. $80-81$ ) by the idea that natural selection is needed to validate our norms of thought, reason and morality. In the world of everyday affairs, there is only one set of rules for sound thought (If A implies B and B implies $\mathrm{C}$, then $\mathrm{A}$ implies $\mathrm{C}$; if $\mathrm{A}$ is true, not $\mathrm{A}$ is false, \&c) which Aristotle codified long ago. The circumstance that natural selection would favor incorporating these rules, however unconsciously, in the thought of some animals has nothing to do with validating these rules.

Nagel thinks that whereas "Thought and reasoning are correct or incorrect in virtue of something independent of the thinker's beliefs, and even independent of the community of thinkers to which he belongs" (p. 72), animals' "lives are lived in the world of appearances, and the idea of an objective reality has no meaning" (p. 73) and that the capacity of human thought to "transcend subjectivity and to discover what is objectively the case" (p. 72) renders human thought and reasoning inexplicable by natural selection. Many agree with him, including the physicist Stephen Barr (2011) and a philosopher with no interest in creationism or intelligent design, Hilary Putnam (1992).

This view, however, must be wrong. First, as Lorenz (p. 24) observes, natural selection of random mutation, retaining only what works best, parallels the acquisition of objective knowledge by a human being who compares "an idea in his mind, a hypothesis he has evolved, with the outside world and 'checks whether it fits." The knowledge encoded in an organism's genome of how to procure sufficient resources from its habitat to grow, survive and reproduce is as objective as the knowledge a scientist gains by trial and error-testing a hypothesis, modifying it as needed, and testing it again. Similarly, unconscious computations in human or monkey eyes abstract the 
existence, shape and color of an object from an array of subjective sense impressions (Lorenz 1978, p. 11). Weyl (2009, p. 199) and Lorenz (p. 11) both remark how these unconscious operations by which we (like other vertebrates) infer a body as the common cause of its various perspective views amount to inferring objectively existing entities from subjective sense impressions. Indeed, Weyl emphasizes the analogy between these unconscious operations and the conscious operations by which physicists infer the existence of molecules, atoms or electrons. If monkeys and cats can unconsciously ascend from subjective data to objective conclusions, why must their consciousness be restricted to the subjective?

Second, the theory of mind, by which one chimpanzee infers the motives, intentions or feelings of another, depends on applying an analogy. As Adam Smith (1759, section I. I. 2) remarked, "As we have no immediate experience of how other men feel, we can form no idea of the manner in which they are affected, but by conceiving what we ourselves would feel in the same situation." The same is true for chimpanzees. Analogy is also a powerful tool in forming theories (Thompson 1942, p. 9n).

Third, primate social life favors intelligence (Jolly 1966). Baboons live in troops of eighty. Each troop has a dominance hierarchy governing access to mates and food or resting sites. A baboon's failure to know its rank in the hierarchy can earn a severe beating; consistent failure may keep it from reproducing. A baboon can recognize, by sight or sound, every other troop-mate. From what a baboon sees and hears of the interactions among its fellow troop members it unconsciously infers the dominance hierarchy and the matrilineal kinship network (who is whose mother, maternal sibling, \&c) of the whole troop (Cheney and Seyfarth 2007, p. 14, 108). Indeed, Cheney and Seyfarth (p. 15, 109) believe that "natural selection has led to the evolution of a mind innately predisposed to search for the patterns and rules that underlie other baboons' behavior," just as children's brains are predisposed to language learning. This abstract, elaborate, objective, often tested theoretical construct provides an economical summary of the social knowledge a baboon needs to survive and reproduce (Cheney and Seyfarth 2007, p. 118).

Objective inference, reasoning by analogy, and inferring, however unconsciously, theoretical constructs that economically summarize social knowledge, all enhance their possessor's fitness. Ritualized games using these abilities, such as poetry, drama, mathematics and theoretical physics, are a form of social play, an outgrowth of the exploratory curiosity so common in many animals (Huizinga 1950; Lorenz 1978). "What is new in exploratory behavior [of animals] is only that the motivation is furnished by the learning process itself," not by satisfying a particular need. "As a result of this apparently small step forward there emerges an entirely new cognitive process... in essence identical to that of human investigation and which leads without an essential break to the activity of scientific research. The connection between play and investigation... is still fully preserved in adult human investigation" (Lorenz 1978, p. 149). Are philosophers too serious to see how important play is for developing intellect?

Indeed, even if animals other than human beings cannot criticize each other except by punishing, out-reproducing or eating the mistaken, they must live in the same objectively real world we do. They must also infer objective truths-the presence of predators, whether a brightly colored animal is advertising its distastefulness by "warning colors" or a tasty mimic of such a distasteful animal, whether an object is an inedible stick or an edible walking stick, detectable by its head and paired legs (Ziegler and Leigh 2012, p. 175-195). There are no surrogate truths: what they know, they must know truly (Lorenz 1978). Weyl (1949, p. 153) quoted Einstein's remark "Nobody who really goes into the matter will deny that the world of perception determines the theoretical system in a virtually unambiguous manner, although no logical way leads to the principles of the theory" (Weyl 1949, p. 153). Likewise, Dennett (2015, p. 175) remarked that, although in theory two anthropologists studying a newly contacted tribe with a totally unknown language could construct different but equally justifiable dictionaries for this language, it would be almost impossible to provide an example.

Finally, Nagel (p. 107) accepts an argument of Sharon Street that "if the responses and faculties that generate our value judgments are... the result of natural selection, there is no reason to expect that they would lead us to be able to detect any mind-independent moral or evaluative truth." As he believes there are objective moral truths, he concludes that natural selection cannot be the only "director" of evolution. C. S. Lewis (1947, chapter 2) argued for a unique objective substrate underlying the world's moral systems, which he called the Tao. Although we have yet to fully discern this Tao (Lewis 1947, p. 30), it can be approximated by Exodus 20: 10-17 and summarized by the demands that we treat others as, in their shoes, we would be treated and that we punish those who violate these norms (Darwin 1871; Ricoeur 1989; Changeux 2008, p. 44). There may well be only one set of basic moral rules that ensure a healthy, sustainable social life. Moreover, perturbing the balance of virtues prescribed by this Tao, exaggerating some and neglecting others, causes massive social suffering (Lewis 1947, p. 29). These virtues may be related to each other by relating them to Plato's idea of the Good (Murdoch 1971, ch. 
3). Can natural selection predispose us to discover these rules?

First, I suggest that interdependence is the real mother of morality. An animal's genes are utterly dependent on each other's correct function. Thanks to the blind mechanism of natural selection, mindless genes communally enforce a rule of fair competition ensuring that genes spread only if they benefit their bearers, thereby serving their fellow genes' common good. An animal's cells are diploid, carrying two sets of the genes encoding the recipe for its growth, survival and reproduction. When it reproduces, it produces haploid gametes, eggs or sperm, with one set of genes apiece. At almost every locus, a gamete has equal chance of receiving its grandmother's or its grandfather's gene, the choice normally being governed by the fairest lottery in all nature. Very rarely, a mutant gene arises that biases this lottery in its own favor by killing most of the "normal" sperm, so that $95 \%$ of the surviving sperm of an adult male with a single copy of this mutant inherit this mutant. This mutant thus spreads rapidly at first. In homozygous individuals with two mutant genes at this locus, mutants are equally nasty to each other. Genes at different loci are so interdependent that when this locus fails to function thanks to having two mutant genes, the animal is stillborn or sterile. Because genes on different chromosomes assort independently of genes at this "distorter" mutant's locus, none of them can spread by "riding the distorter's coattails." Because the distorter kills its homozygotes, a mutant on another chromosome that restores the lottery's fairness will out-reproduce its fellows by sparing some of its descendants the death they would otherwise have suffered from this distorter's spread. In short, this lottery's fairness is enforced by a selection that favors the common good of the animal's genes. Similarly, injustice tends to destroy society, so punishing injustice and enforcing fairness serves the common good of a society's members (Smith 1790, part II, section ii, chapter 3, paragraph 8). Moreover, fair competition usually benefits society (Smith 1776). Curiously, mechanistic selection among genes has done far better than human beings of modern societies in making competition fair.

In sentient animals, interdependence also breeds moral instincts. In Book I, 351c of his Republic, Plato observed that a gang of thieves only functions effectively if they treat each other fairly. In hunter-gatherer societies, which tend to have roughly thirty members apiece, each member's survival depends on the willing cooperation of all the others. Their unity of purpose depends on treating each other fairly and punishing the unfair (Boehm 2012). "No tribe could hold together if murder, robbery, treachery, \&c., were common; consequently such crimes within the limits of the same tribe 'are branded with everlasting infamy." (Darwin 1871, p. 93). Similarly, "All animals living in a body which defend each other or attack their enemies in concert, must be in some degree faithful to each other" (Darwin 1871, p. 78f). Moreover "actions are regarded by savages, and were probably so regarded by primeval man, solely as they affect in an obvious manner the welfare of the tribe,- not that of the species, nor that of... an individual member" (Darwin 1871, p. 96). Darwin therefore concluded that the moral sense evolved from the social instincts, both originally serving the tribe's good. Thus courage, self-sacrifice, self-control and fidelity were prized, but the weak might be expelled to enable the tribe's survival (Darwin 1871, p. 96, 77). Since social instincts evolved for the tribe's good, sympathy was normally confined to its members (Darwin 1871, p. 93-94, 97), just as social animals normally extend services only to fellow group members (Darwin 1871, p. 72).

In tribal life, as in the life of social animals, the response to another's needs must often be quick. Such responses cannot wait for conscious calculation, they must be rooted in instinctive sympathy for fellow group members. These instincts are deeply rooted: long before it reasons, a baby, like a playing dog or wolf, will cease a form of play that elicits distress in a companion (Changeux 2008, p. 52), a phenomenon known as "violence inhibition." Such fellow-feeling should keep one from imposing serious harm on a fellow group member to procure a slight benefit for oneself, a phenomenon Nagel (p. 100) thought inexplicable by natural selection. Indeed, in a small, tightly interdependent group one cannot afford the luxury of asking "Why should I be the one to sacrifice my life for the group?" for taking time to ask could kill one's whole group.

By themselves, social instincts do not a morality make. Reason must judge between conflicting instincts (Lewis 1947, p. 23). Darwin (1871, p. 106) argued that "the social instincts-the prime principles of man's moral constitution-with the aid of active intellectual powers and the effects of habit, naturally lead to the golden rule, 'As ye would that man should do unto you, do ye to them likewise;' and this lies at the foundation of morality." As small tribes are united into larger communities, reason should tell each person to extend the golden rule, first to all members of his nation, then to all human beings (Darwin 1871, p. 100). This is still a work in progress. As society enlarges and interdependence within families and local groups weakens, social instincts weaken also weaken, and reason must take over from natural selection in promoting morality. Nowadays, reasoned morality is often supplanted by cruder instincts.

The tragedy of Nagel's thought-provoking, stimulating book is, as he realizes, its lack of convincing alternatives to materialism. Nagel seeks special features of 
matter that make it possible for consciousness to evolve, but isn't this just expanding our understanding of matter? Lacking other approaches, biologists will push the materialist approach as far as they can. The best of them, like Changeux (2008), will seek full explanations of consciousness, learning and moral judgment. Nagel wonders whether a teleology inherent in nature, such as Aristotle's, unconnected with any god (Gilson 1971) will explain the origin of life and evolution of adaptation. Because selection promotes the common good of autosomal genomes, selection-theory, however, makes far more specific predictions than Aristotelean teleology ever could about phenomena such as kin selection, the maintenance of fair meiosis against challenges from "distorter" alleles, sex ratio at birth, and the like.

Mary Midgley's Are You an Illusion?, written when she was 94, was triggered (p. 5) by an outrageous claim by Francis Crick of DNA fame: "You, your joys and sorrows, your memories and your ambitions, your sense of personal identity and your free-will, are in fact no more than the behaviour of a vast assembly of nerve-cells and their attendant molecules." She is a philosopher whose first book, Beast and Man (Midgley 1978), was a remarkably balanced critique of E. O. Wilson's (1975) bitterly controversial Sociobiology. She followed this by Animals and Why They Matter (Midgley 1983), a well-written, clearly reasoned assessment of human duties toward animals. Her writings abound in the plain horse sense so characteristic of Aristotle and Darwin, and so sorely lacking in many modern academics. In this book, she criticizes various aspects of neo-Darwinism and the world-view she thinks it reflects, mostly for what it ignores.

First, she is revolted by certain "nothing-but" reductionisms associated with this world-view, such as Crick's remark, just quoted. We are in fact functional beings whose nerve-cells can do nothing without our bodies: why replace a perfectly good functional explanation by a promised mechanical explanation whose fulfillment no one can yet guarantee, and which, if fulfilled, would probably be much less insightful?

Second, the materialistic world-view underlying neoDarwinian writings often privileges the objective over the subjective, ignoring mind, intention and consciousness as immune to objective analysis, and too immaterial to affect the material world. She delights (p. 73-75) in haling forth sexual selection as visible evidence of how female intentions and aesthetic preferences can drive evolution: Dawkins (2009, p. 45-54) discussed the ways flowers attract pollinators to illustrate the power of natural selection driven by animal choice. Indeed, ignoring what our consciousness can tell us is crippling, as the materialist Jacques Monod (1971, p. 159) recognized. The mathematician and theoretical physicist Hermann Weyl
(1949, p. 283) remarked "Scientists would be wrong to ignore the fact that [objective] theoretical construction is not the only approach to the phenomena of life; another way, that of [subjective] understanding from within (interpretation) is open to us... Its illuminating light is directed not only on my fellow man: it also reaches, although with ever-increasing dimness and incertitude, deeply into the animal kingdom." Any ethologist knows the importance of "trying to put herself in her study animal's shoes": Midgley (p. 17-20, 31) shows how failure to take into account the intentions and emotions of animals stunted the study of animal behavior. About six pages into The Secret of Father Brown, G. K. Chesterton (1951, p. 639) reveals both the moral and the cognitive damage from ignoring our understanding from within:

\begin{abstract}
"What do these men mean... when... they say criminology is a science? They mean getting outside a man, and studying him as if he were a gigantic insect; in what they would call a dry impartial light; in what I should call a dead and dehumanized light... I don't deny that the dry light may sometimes do good, though in one sense... far from being knowledge, it's actually suppression of what we know. It's like treating a friend as a stranger... [Instead] I try to get inside the murderer... I am inside a man. I am always inside a man... but I wait until I am inside a murderer, thinking his thoughts, wrestling with his passions, till I have bent myself into the posture of his... hatred."
\end{abstract}

Privileging the objective over the subjective has also led to divorcing fact from value and reason from emotion and feeling, even though the crucial role of aesthetics in Einstein's general theory of relativity belies the first, and the second claim flies in the face of modern, deliberately materialistic neurobiology (Damasio 2003). Moreover, these divorces have privileged science over the arts and promoted science as the only way of knowing, which has done nothing to enhance either the effectiveness of education or the quality of its content (Nussbaum 2010).

Third, Midgley doubts whether biology can be reduced to physics and chemistry. Like Changeux (2008), she realizes that the philosophy of matter needs updating (p. 88): Aristotle's concept of matter, still unreflectively assumed by many humanists, is vastly oversimplified (Weyl 1949). Nonetheless, she doubts whether mind can be explained entirely in terms of matter. The laws of physics are the same whether run forward or backward (p. 136), whereas our own lives, the evolution and diversification of living things, the history of the universe, and the second law of thermodynamics are all characterized by a direction in time (Prigogine 1997, Smolin 2013). Midgley wonders whether physics is too transfixed by the idea of an 
"imagined, changeless, abstract, transcendent universe" (p. 138) to be the only foundation of biology. More generally, she believes that there are other ways of knowing besides science (p. 2): "But the way in which the universe works isn't confined to the things that the sciences tell us about it."

Fourth, Midgley considers it thoroughly inappropriate to declare the universe meaningless in the name of atheistic materialism (p. 82, 85-89, as do Monod (1971) and Dawkins (1976). Like the agnostic Darwin (1969, p. 92-93), she sees plenty of meaning in the story of our planet. Moreover, she is as hesitant as Darwin to try to destroy the meaning other people see in their lives.

Finally, she finds modern selection-theory problematic. She doubts the "creativeness" of natural selection, which she considers merely a filter (p. 16, 71) rather than a continuing feedback where organisms produce varied offspring which are tested by the environment, of which the best survive to repeat the process (Lorenz 1978, pp. $24,27)$. She must believe that the true origin of species is more linked to the origin of variation than to natural selection. She remarks (p. 82): "The total reliance of natural selection on chance was simply not compatible with the notion of any fixed direction." Artificial selection, however, which depends as much on "chance variation" as its natural sister, is often quite directional. Nor are the demands the environment makes on the practitioners of a given way of life more capricious than a human breeder's demands. She doubts whether, even given adequate variation, natural selection can account for the exuberant variety of life, because (p. 77,90$)$ she cannot see how all the varied features of living beings are related to surviving in order to reproduce. She does not understand kin selection, which is curious, for its role in the evolution of insect societies seems obvious to most biologists. She has been unduly excoriated for this failure. She prefers to speak of group selection. Like Darwin (1871, p. 166) she believes, as I do (Leigh 2010), that group selection played a central role in the evolution of morality in hunter-gatherer tribes (Midgley 2010, p. 25-27). She does not understand why the concept of group selection fell into such disrepute, which it always does when not formulated in a way that allows quantitative analysis.

Her greatest difficulty is with viewing natural selection as competition (p. 69), which it undoubtedly is. She associates this view with Margaret Thatcher's politics: does she think that competition always implies overt contest? She recalls (p. 65-66) an article whose authors, thinking that natural selection only favors individual advantage, puzzled over how language, which shares useful information with others, could evolve. How could they fail to see that if members of a group can communicate in order to cooperate, they would all survive better? She despises the idea that genes are utterly selfish (p. 69-70, 82-83). After all, these genes are utterly interdependent because their organism can survive and pass them on to offspring only if nearly every gene in its genome does its job appropriately. Thanks to their interdependence, selection on these selfish genes enforces a moral code that ensures that an allele only spreads by promoting its autosomal genome's common good. Her rejection of competition is sad, for evolution, like Adam Smith's (1776) economics, reflects the intimate interplay of competition and cooperation: neglect either, and gross misunderstanding results.

To summarize: Midgley's book flags many misguided directions in biology. Although she knows and appreciates Darwin's work far better than most, this book is curiously distrustful of natural selection. Does she conflate the gene- (or genome-) centered approach to evolution, which emphasizes kin selection, with Dawkins's (1976) views (since moderated) on arrant gene selfishness? We evolutionary biologists must take care what spin we put on our explanations.

In sum, I do not know how consciousness works, or the likelihood of variation that would allow natural selection to bring forth moral instincts, objective knowledge and conceptual thought. Nonetheless, Darwin (1871) and Lorenz (1978) showed how consciousness, objective knowledge, conceptual thought and moral instincts enhance their possessors' survival and reproduction. I also think that excessive eagerness to associate natural selection with selfishness-an error Darwin avoidedhas distorted reality in a way that creates unnecessary suspicion of science in general and evolutionary biology in particular.

\section{Competing interests}

The author declares that he has no competing interests.

Received: 5 February 2016 Accepted: 8 February 2016

Published online: 17 February 2016

\section{References}

Barr SM. Modern physics and ancient faith. Notre Dame: Notre Dame University Press; 2011.

Behe MJ. Darwin's black box: the biochemical challenge to evolution. New York: Simon and Schuster; 1996.

Boehm C. Moral origins: the evolution of virtue, altruism and shame. New York: Basic Books; 2012.

Changeux J-P. Du vrai, du beau, du bien: Une nouvelle approche neuronale. Paris: Odile Jacob; 2008.

Cheney DL, Seyfarth RM. Baboon metaphysics. Chicago: University of Chicago Press; 2007.

Chesterton GK. The father Brown omnibus. New York: Dodd, Mead; 1951.

Damasio A. Looking for spinoza: joy, sorrow and the feeling brain. Orlando: Harcourt; 2003.

Darwin C. The descent of man, and selection in relation to sex. London: John Murray; 1871.

Darwin C. The autobiography of Charles Darwin, 1809-1882. New York: Norton; 1969 
Dawkins R. The selfish gene. Oxford: Oxford University Press; 1976.

Dawkins R. The greatest show on earth: the evidence for evolution. New York: Free Press; 2009.

Dennett DC. Intuition pumps and other tools for thinking. New York: Norton; 2015

Fisher RA. The genetical theory of natural selection. Oxford: Clarendon Press; 1930.

Gilson E. D'Aristote à Darwin et retour. Paris: J. Vrin; 1971.

Huizinga J. Homo ludens: a study of the play element of culture. New York: Roy; 1950.

Lane N. The vital questions: energy, evolution and the origin of complex life. New York: Norton; 2015.

Leigh EG Jr. The group selection controversy. J Evol Biol. 2010;23:6-19.

Lewis CS. The abolition of man. New York: Macmillan; 1947.

Lorenz K. Behind the mirror: a search for the natural history of human knowledge. New York: Harcourt Brace Jovanovich; 1978.

Midgley M. Beast and man: the roots of human nature. Ithaca : Cornell University Press; 1978.

Midgley M. Animals and why they matter. Athens: University of Georgia Press; 1983.

Midgley M. The solitary self: Darwin and the selfish gene. New York: Routledge; 2010

Monod J. Chance and necessity. New York: Vintage Books; 1971.

Murdoch I. The sovereignty of good. London: Routledge and Kegan Paul; 1971.
Nussbaum M. Not for profit: why democracy needs the humanities. Princeton: Princeton University Press; 2010.

Prigogine I. The end of certainty. New York: Free Press; 1997.

Putnam H. Renewing philosophy. Cambridge: Harvard University Press; 1992.

Ricoeur P. L'éthique, la morale, et la règle. Autres Temps: Les cahiers du christianisme social. 1989;24:52-9.

Smolin L. Time reborn: from the crisis in physics to the future of the universe. London: Allen Lane; 2013.

Smith A. The Theory of Moral Sentiments, sixth edition. London: Strahan and Cadell; 1790.

Smith A. An enquiry into the nature and causes of the wealth of nations. London: Strahan and Cadell; 1776.

Thompson DW. Growth and form, 2nd ed. Cambridge: Cambridge University Press; 1942.

Weyl $\mathrm{H}$. The philosophy of mathematics and natural science. Princeton: Princeton University Press; 1949.

Weyl $\mathrm{H}$. The unity of science. In: Pesic P, editor. Hermann Weyl: Mind and matter, selected writings on philosophy, mathematics and physics. Princeton: Princeton University Press; 2009. p. 194-203.

Wilson EO. Sociobiology: the new synthesis. Cambridge: Harvard University Press; 1975.

Ziegler C, Leigh EG Jr. A magic web. Balboa: Smithsonian Tropical Research Institute; 2012.

\section{Submit your manuscript to a SpringerOpen ${ }^{\odot}$ journal and benefit from:}

- Convenient online submission

- Rigorous peer review

- Immediate publication on acceptance

- Open access: articles freely available online

- High visibility within the field

- Retaining the copyright to your article

Submit your next manuscript at $>$ springeropen.com 